Published in final edited form as:

Curr Opin Pulm Med. 2015 May ; 21(3): 260-271. doi:10.1097/MCP.0000000000000156.

\title{
Pneumonia in the neutropenic cancer patient
}

\author{
Scott E. Evans, MD and David E. Ost, MD, MPH \\ The University of Texas MD Anderson Cancer Center, Department of Pulmonary Medicine
}

\begin{abstract}
Purpose of review-Pneumonia is the leading cause of death among neutropenic cancer patients, particularly those with acute leukemia. Even with empiric therapy, case fatality rates of neutropenic pneumonias remain unacceptably high. However, recent advances in the management of neutropenic pneumonia offer hope for improved outcomes in the cancer setting. This review summarizes recent literature regarding the clinical presentation, microbiologic trends, diagnostic advances and therapeutic recommendations for cancer-related neutropenic pneumonia.
\end{abstract}

Recent findings-While neutropenic patients acquire pathogens both in community or nosocomial settings, patients' obligate healthcare exposures result in the frequent identification of multidrug resistant bacterial organisms on conventional culture-based assessment of respiratory secretions. Modern molecular techniques, including expanded use of galactomannan testing, have further facilitated identification of fungal pathogens, allowing for aggressive interventions that appear to improve patient outcomes. Multiple interested societies have issued updated guidelines for antibiotic therapy of suspected neutropenic pneumonia. The benefit of antibiotic medications may be further enhanced by agents that promote host responses to infection.

Summary-Neutropenic cancer patients have numerous potential causes for pulmonary infiltrates and clinical deterioration, with lower respiratory tract infections among the most deadly. Early clinical suspicion, diagnosis and intervention for neutropenic pneumonia provide cancer patients' best hope for survival.

\section{Keywords}

Neutropenia; pneumonia; leukemia; cancer; galactomannan

\section{Introduction}

Worldwide, pneumonia profoundly impacts all populations.(1-4) However, the impact of pneumonia on cancer populations is uniquely severe, accounting for more morbidity and mortality than any other infectious complication.(5-13) This review addresses the

\footnotetext{
Correspondence: David Ost, 1515 Holcombe Blvd, Unit 1100, Houston, Texas 77030, dost@mdanderson.org, Phone: 713-745-8775.

Conflicts of interest

DEO has no financial conflicts of interest to disclose.

SEE is an author on US Patent 8,883,174 entitled "Compositions for stimulation of mammalian innate immune responses to pathogens," and owns stock in Pulmotect, Inc., a company that has licensed technology referenced in this manuscript for clinical development.

Financial Support

None.
} 
epidemiology, pathophysiology, microbiology, diagnostics, and therapeutics relevant to clinical care of pneumonia in neutropenic cancer patients, with particular emphasis on recent guidelines.

\section{Epidemiology}

Lower respiratory tract infections are strikingly common among cancer patients. Reports indicate that $13-31 \%$ of leukemia patients receiving chemotherapy $(8-10,12-14)$ and up to $80 \%$ of hematopoietic stem cell transplant (HSCT) recipients will experience at least one episode of pneumonia. $(15,16)$ The mortality attributable to pneumonia in these populations is very high with case fatality rates in leukemia patients ranging from $25 \%-80 \%(11,17,18)$ while the case fatality rate in HSCT recipients is as high as $90 \% .(8-10,12-14,18-23)$

\section{Pathophysiology and Host Factors}

Both cancer and its treatment induce derangements of innate and adaptive immune function. Leukocyte depletion, dysregulated inflammation, impaired pathogen recognition, and graftversus-host responses contribute to cancer patients' tremendous susceptibility to lower respiratory tract infections. Functional and anatomical defects frequently coexist in cancer patients. Further, recurrent healthcare encounters that are typical among cancer patients promote exposure to nosocomial and drug resistant pathogens.

Among the risks for cancer related pneumonia, neutropenia is the most prominent. Neutrophils are sensitive to alkylating agents and nucleoside analogs, resulting in dose dependent reductions in the absolute neutrophil count. Severe neutropenia, defined as a count $500 / \mu \mathrm{L}$, is associated with severe lung infections caused by bacterial and fungal organisms.(24) The rapidity of onset, duration, severity, and underlying physiologic process all impact susceptibility to neutropenic pneumonia.(7, 20, 25-30) Moreover, impairments of neutrophil phagocytosis and chemotaxis follow such common cancer-related insults as radiation, corticosteroids, hypovolemia, acidosis, and hyperglycemia.(31) Thus, functional neutropenia can also contribute to cancer-related pneumonia risk.

\section{Microbiology and the Spectrum of Pathogens}

The spectrum of pathogens to which neutropenic patients are susceptible is staggeringly broad (see Table 1). It is, therefore, helpful to consider the site of acquisition, because this impacts the spectrum of pathogens and their antimicrobial resistance patterns and therefore determines optimal treatment strategy.

\section{Community acquired organisms}

Genuine community acquired pneumonia (CAP), defined as development of pneumonia in patients that have not been hospitalized or resided in a nursing home for $\geq 14$ days prior to the onset of symptoms, and who do not meet criteria for other risk groups,(32-34) is relatively uncommon among cancer patients, owing to their frequent healthcare exposures. (35) This is particularly true among neutropenic patients, since this typically reflects recent chemotherapy. Nonetheless, outpatient neutropenic individuals routinely encounter 
community pathogens, so physicians must consider CAP organisms when approaching patients with neutropenic pneumonia.

The most frequent agent of bacterial CAP remains Streptococcus pneumoniae, including in the cancer setting. $(36,37)$ Other causes of CAP among neutropenic patients include Staphylococcus aureus, Pseudomonas spp., and nontypeable Hemophilus influenzae. Nonfermenting-Gram-negative bacilli (NF-GNB), such as Stenotrophomonas maltophilia, Burkholderia spp., Chryseobacterium meningosepticum, and Alcaligenes (Achromobacter) spp., are increasingly recognized as etiologic agents in both CAP and nosocomial pneumonias.(38-45) Streptococcus pyogenes, Neisseria meningitides, and Moraxella catarrhalis are less frequent causes of CAP. Atypical pathogens such as Mycoplasma pneumoniae, Chlamydophyla pneumoniae, and Legionella spp. also cause CAP in this population. The community acquired viruses most frequently causing CAP in neutropenic patients include influenza viruses, parainfluenza viruses, human metapneumovirus, and adenoviruses.

While community acquired organisms cause pneumonia in neutropenic patients, it is crucial to recall that neutropenic patients do not respond to pathogens in similarly to nonneutropenic individuals. What might be an easily cleared inoculum for an immunocompetent patient may cause life threatening pneumonia in the setting of neutropenia. Guidelines for CAP management were developed for patients without immune dysfunction. $(32,46)$ Consequently, clinical scoring strategies to direct management of CAP, such as the Pneumonia Severity Index (PSI) and the CURB-65, may underestimate the severity of illness in the neutropenic population and should be used with caution.(35)

\section{Nosocomial bacterial pathogens}

By virtue of their health care interactions, most neutropenic outpatients are typically best categorized as having healthcare associated pneumonia (HCAP), rather than CAP. Formally, HCAP encompasses pneumonia that develops in outpatients who have been hospitalized for $\geq 2$ days in the prior 90 days, received treatment in a hospital or hemodialysis clinic, resided in long-term care facilities, received intravenous antibiotics, chemotherapy or wound care in the prior 30 days.(47) This definition is contrasted with hospital acquired pneumonia (HAP), wherein pneumonia develops $\geq 48$ hours after hospital admission, or ventilator associated pneumonia, which develops $>48-72$ hours after endotracheal intubation.(47) The spectrum of pathogens causing HCAP substantially overlaps that of late onset HAP or VAP, $(47,48)$ and the available guidelines for management of these nosocomial infections overlap.(47)

The bacterial causes of nosocomial pneumonias in cancer patients without recent antibiotic exposure include $S$. pneumoniae, S. aureus, and $H$. influenzae. In those with cancer patients with neutropenia, additional pathogens to be considered are the Gram-negative enteric organisms, including Pseudomonas spp., Klebsiella pneumoniae, Escherichia coli, Enterobacter cloacae, S. maltophilia, Citrobacter spp., Serratia marcescens, Acinetobacter baumannii-complex and Proteus spp.(15, 41, 43, 44, 49-52) Unfortunately, the rise in Gram-negative neutropenic respiratory infections has also yielded a corresponding increase in extended spectrum beta-lactamase producing Enterobacteriaceae. Mortality rates associated with drug resistant $P$. aeruginosa and MRSA are disproportionately higher than 
those caused by other nosocomial bacterial pathogens.(53) Finally, sporadic outbreaks of Legionella pneumophila and Norcardia spp. have occasionally been reported by various transplant centers and should be considered depending on the context (54-56).

\section{Fungi}

While bacterial pathogens cause documented neutropenic pneumonias about twice as often as fungi, $(13,27)$ invasive pulmonary mycoses are associated with significant morbidity and mortality. Aspergillus is the most common fungal pneumonia in neutropenic patients, with Aspergillus fumigatus being the most frequently cultured of this genus, although A. flavus, A. niger, and amphotericin B-resistant $A$. terreus have also emerged as important pathogens. $(57,58)$ Risk factors for aspergillus pneumonia include both duration (> 1 week) and severity ( $<100$ cells $/ \mu \mathrm{L})$ of neutropenia.(59-61) Non-Aspergillus molds such as Fusarium spp., Pseudaalesheria boydii, Scedosporium spp., and the dematiaceous molds that are often not susceptible to conventional antifungal agents are also described in this population.(62, $63)$.

Widespread use of fluconazole prophylaxis appears to have induced a decline in pneumonias caused by endemic mycoses, such as Histoplasma capsulatum, Blastomycetes dermatitidis, and Coccidioides immitis. However, neutropenic pneumonias caused by zygomycetes (mainly mucorales) have increased in recent years, corresponding with increased use of voriconazole and declining use of amphotericin B (to which these organisms are more often susceptible).(63)

While Pneumocystis jiroveci pneumonia is typically seen in patients with CD4+ cell depletion, this organism must also be considered as a cause of neutropenic pneumonia, particularly in patients with severe hypoxemia. $(64,65)$ Because of the effectiveness of trimethoprim-sulfamethoxazole prophylaxis during the neutropenic period after HSCT, most Pneumocystis in HSCT patients is now seen among sulfa-allergic patients receiving less effective prophylaxis.(66)

\section{Viruses}

The incidence of CMV infection has declined in recent years due to aggressive prophylaxis and preemptive therapy, but active infections continue to cause severe morbidity, especially among seronegative HSCT recipients.(67-69) Detection of CMV viremia or antigenemia strongly suggests active disease, whereas detection of CMV in lower respiratory tract secretions may reflect viral shedding without active infection. Consequently, the observation of cytopathic changes can help in diagnosing CMV pneumonia. Respiratory syncytial virus (RSV) pneumonia is relatively uncommon in the neutropenic adult population, but is associated with very high mortality rates. $(40,70)$ Other less common causes of viral lower respiratory tract infections include varicella-zoster and human herpes virus 6.

\section{Mycobacteria}

Mycobacterium tuberculosis is a rare cause of neutropenic pneumonia, typically seen among foreign-born individuals receiving cancer care in non-endemic regions.(71) Most cases are reactivation episodes of latent infections rather than de novo infections. Conversely, 
nontuberculous mycobacterial lower respiratory tract infections are widely reported among neutropenic patients.(72)

\section{Polymicrobial}

Polymicrobial isolates are common among patients with neutropenic pneumonia.(73) Because of the frequency with which multiple organisms are identified on respiratory samples, recent guidelines support the use of semi-quantitative or quantitative cultures in patients with suspected HCAP, HAP and VAP.(47) An unfortunate consequence of frequent polymicrobial infections is that a positive test for one pathogen does not necessarily allow withholding of empiric therapies for other pathogens.

\section{Diagnostics}

Evaluation of neutropenic cancer patients with suspected pneumonia requires careful clinical and microbiologic assessment, supplemented by selected molecular testing for particular pathogens.

\section{Clinical assessment}

The classical clinical signs of pneumonia in most populations include new pulmonary infiltrates, leukocytosis, fever, and purulent secretions. However, due to disordered host inflammatory responses in the neutropenic cancer patient, these clinical and radiographic hallmarks may be unapparent. $(25,40,41,47,62)$ Thus, early CT scanning is warranted for neutropenic patients with unanticipated clinical deterioration, unexplained fevers or questionable infiltrates on conventional imaging.(40, 41, 62)

However, the differential diagnosis of pulmonary infiltrates is expansive and includes such noninfectious mimics as leukemic infiltrates, drug toxicity, and hydrostatic pulmonary edema. Thus, while infection remains the most frequent cause of these radiographic abnormalities in neutropenic patients, $(13,21,22,27,45,74)$ the potential diagnoses are numerous and the challenge is to identify those patients who are most likely to benefit from further investigations in addition to empiric antimicrobial therapy.(21, 22, 45, 74)

\section{Microbiologic assessment}

Neutropenic pneumonia is most reliably diagnosed when a likely pathogen is recovered from a typically sterile site or when a non-commensal organism is isolated from respiratory secretions. Although practice patterns vary widely,(75) bronchoscopy with bronchoalveolar lavage (BAL) is the diagnostic tool of choice for obtaining lower respiratory samples from neutropenic cancer patients. $(8,76) \mathrm{BAL}$ is safe for most cancer patients, $(8)$ although traditional culture methods yield a definite pathogen in only $25-51 \%$ of cases. $(8,19,76-79)$ The diagnostic benefit of BAL is likely greatest when performed early, particularly if it can be done prior to the initiation of antimicrobial therapy. $(8,76,80)$ However, therapy should not be delayed so that a BAL can be done, since the detrimental effects of delays in treatment outweigh the modest gains recognized by having improved BAL sensitivity. When feasible, transbronchial biopsies (TBBx) may reveal angioinvasion by microbes (e.g., Aspergillus spp.), however culturing TBBx material has not been proved superior to $\mathrm{BAL}$ 
and TBBx carries a higher risk of complications such that it is often precluded in neutropenic patients because of concurrent thrombocytopenia.

Interpretation of BAL culture data can be challenging, due to frequent colonization of the upper airway with nonpathogenic microorganisms.(41) Autopsy studies suggest that in the presence of sufficiently severe immunosuppression, many organisms that are usually considered as colonizers can cause significant disease. Thus, the clinician must carefully assess each patient to determine the appropriateness of responding to positive culture results. Conversely, sterile cultures do not exclude infection, particularly in the setting of prior antibiotic utilization. $(40,41)$ These diagnostic challenges have promoted the use of modern molecular techniques to enhance the sensitivity of BAL and to facilitate the discrimination of bona fide pathogens from irrelevant commensals. Such techniques include polymerase chain reaction (PCR) testing and antigen detection methods. $(41,45,81)$

\section{Molecular Testing for Galactomannan as a Test for Invasive Aspergillosis}

Early diagnosis of invasive Aspergillosis (IA) remains problematic, because microbiologic proof is often not possible. $(82,83)$ IA may be suggested by CT findings which may include nodular infiltrates, with or without cavitation, sometimes with patchy or segmental consolidation.(84) Peribronchial infiltrates and tree-in-bud patterns can also be seen, and radiographic findings vary with host factors and the degree of immunosuppression. As highlighted in Figure 1, while CT imaging may be suggestive of IA, the range of potential radiographic patterns overlaps with other causes of pneumonia. Thus, CT imaging is not sufficient to make a definitive diagnosis.

Because sputum and BAL cultures have limited sensitivity,(85-87) there has been increasing interest in molecular tests and immunoassays for diagnosing IA. The best characterized clinically available assay is the Platelia galactomannan (GM) assay, which has been approved by the US Food and Drug Administration (FDA) for use on serum and BAL.

GM is a heat-stable polysaccharide found in the cell wall of Aspergillus spp. Immunoassays have been developed to test for GM in serum and BAL to aid clinical diagnosis.(88-90). The FDA-approved GM EIA presents results as a ratio of the test sample optical density relative to a provided control optical density; optical density ratios $\geq 0.5$ (the "optical index") are considered positive. Once thought specific for Aspergillus, it is now clear that the galactofuranose side chain epitopes targeted by the EIA may react with Fusarium spp., Penicillium spp. and Histoplasma capsulatum.(91-93) False positive serum GM tests have been reported in patients receiving certain formulations of piperacillin-tazobactam,(94) however subsequent studies suggest that current preparations of piperacillin-tazobactam do not generate cross-reactivity.(95)

Several strategies of GM testing have been evaluated, including: 1) testing BAL and serum in patients with suspected disease and 2) screening serum of high risk patients without current evidence of disease. These strategies are reviewed below. Because cultures are frequently negative and tissue usually cannot be obtained, the reference standard for many of these studies has therefore been the EORTC/MSG consensus group standards which categorize cases as none, possible, probable or proven. $(96,97)$ 
BAL GM and serum testing in patients with suspected disease-A meta-analysis of 30 studies found that BAL GM testing had a pooled sensitivity of 0.87 (95\% CI 0.79 0.92 ) and pooled specificity of 0.89 (95\% CI $0.85-0.92)$.(98) The pooled likelihood ratio positive was 8.0 (95\% CI 5.7-11.1) and the pooled likelihood ratio negative was 0.15 (95\% CI 0.10-0.23). Sources of heterogeneity identified included differences in study design (cohort vs case-control studies), study size, prior exposure to antifungals, and neutropenia status.

In addition, the optical density ratios that were used to define positive GM assays varied between studies, and this variation in threshold values had a moderate influence on heterogeneity. The optimal threshold value for defining positive results is an area of ongoing debate. In a retrospective study of 251 consecutive patients undergoing BAL GM testing, a threshold $\geq 0.8$ had a sensitivity of $86.4 \%$ and a specificity of $90.7 \%$, resulting in a positive predictive value (PPV) of $81 \%$ and a negative predictive value (NPV) of 93.6\%.(99) Adjusting the threshold to $\geq 3.0$ resulted in a specificity of $100 \%$, while lowering the threshold to $<0.5$ resulted in a very high sensitivity.

On balance, the available evidence for routine use of BAL GM in neutropenic patients with pneumonia is inconclusive. A recent prospective observational cohort study of 568 patients with hematologic malignancies found that BAL GM had a 50\% sensitivity, $73 \%$ specificity, $16 \%$ PPV, and $93 \%$ NPV for proven or probable IA.(84) With the posterior probability of disease ranging from $7 \%-16 \%$, it would be difficult to justify using GM testing in this clinical context to decide on whether to start or stop antifungal therapy. However, depending on the threshold used and the pretest probability, BAL GM might be useful in select cases.

Screening with GM in patients without clinical evidence of disease-A metaanalysis identified 27 studies that evaluated surveillance with serum GM testing for IA in high risk populations that used the EORTC/MSC consensus group or similar criteria as the reference standard.(100) The EORTC/MSG consensus group categorize IA cases as none, possible, probable or proven. $(96,97)$ Using proven IA as the outcome, serum GM had a pooled sensitivity of 0.71 (95\% CI $0.68-0.74$ ) and specificity of 0.89 (95\% CI $0.88-0.90$ ). (100) If the outcome was proven or probable IA the pooled sensitivity was $0.61(95 \% \mathrm{CI}$ $0.59-0.63$ ) and specificity was 0.93 (95\% CI 0.92-0.94). Overall these findings were consistent with moderate accuracy, despite significant study heterogeneity. Subgroup analysis revealed significant test characteristic variability depending on whether the outcome was proven vs proven and probable, the patient population, the reference standard, and the threshold values used for defining positive (Tables 2 and 3). GM testing performed best in patients with hematologic malignancies and HSCT. Overall accuracy of GM testing improved somewhat when a higher threshold was used to define positive results.(100)

On balance, the available evidence for the use of weekly or twice weekly screening with GM testing for high risk patients remains inconclusive. There are no large prospective randomized trials using this screening strategy and it is not clear whether antifungal therapy could be withheld if the results were negative and clinical suspicion was high. Costeffectiveness is also an issue. Important variables to consider include the underlying disease, the pretest probability of disease, what optical density threshold should be used, the relative 
magnitude of the consequences of false positive and false negative tests, and whether or not the information obtained will be actionable.

\section{Therapeutic Strategies}

The value of the information obtained from any of the above diagnostic tests is contingent on having effective therapeutic alternatives. Because of the broad range of potential pathogens, therapeutic strategies must integrate a variety of potential tools, including antibiotics, antifungals, antivirals, and host directed therapies.

\section{Antibiotic therapies}

Treatment should generally not be withheld while diagnostic interventions are undertaken. Delays in appropriate antimicrobial therapy increase the risk of secondary complications and infection-associated deaths in neutropenic patients, thus it is common practice to initiate empiric and/or preemptive antimicrobial therapy when neutropenic pneumonia is suspected. $(41,101,102)$ No consensus exists for the optimal time to first antibiotic dose, but one recent study suggests that neutropenic fever outcomes are better when antibiotics are delivered within 104 minutes of presentation.(30) Most clinicians would endorse the earliest possible dosing, with a possible exception when bronchoscopic evaluation is immediately available. In that case, it may be reasonable to hold empiric antibiotic therapy until completion of the brief procedure, potentially enhancing the diagnostic yield of the collected microbiologic cultures, but this delay should not be longer than 2 hours. Antibiotics should not be held for hours or days in anticipation of bronchoscopy, as the harm from delaying therapy outweighs the benefits of improved test performance.

Initial antimicrobial therapy for febrile neutropenia in patients with pulmonary infiltrates cover the broad range of pathogens described above, with particular emphasis on antimicrobial activity against multi-drug resistant strains of $S$. aureus and $P$. aeruginosa.(22, $25,41,102)$ Antibiotic selection should be based on culture data, pneumonia severity, local antibiotic sensitivity profiles, and patient immune status. $(32-34,46)$ Empiric antibiotics for early HAP (i.e., within seven days of admission) should include coverage of S. pneumoniae, MRSA, $H$. influenzae, and Enterobacteriaceae. Initial regimens for patients with late HAP, HCAP or VAP should ensure enhanced coverage for multi-drug resistant GNB. $(22,41,102)$ Secondary antibiotic selections for patients with refractory HAP, HCAP or VAP should be determined by institutional pathogen susceptibility profiles and on prior patient antimicrobial exposures. $(25,48,102)$

Early de-escalation of broad empiric therapy may be considered in patients who demonstrate prompt clinical response and in whom granulocyte recovery has occurred, especially if a susceptible pathogen has been identified.(25) De-escalation should be undertaken with caution in patients with poor clinical response to antimicrobial therapy, persistent neutropenia, or ongoing immunosuppressive therapy. $(25,41,102)$

Antifungals-Early initiation of effective antifungal coverage is associated with improved outcomes in neutropenic pneumonia.(103) Suspected invasive fungal infections in neutropenic patients requires coverage for Aspergillus spp. Amphotericin B remains a 
treatment option for life threatening aspergillosis, as well as cryptococcosis, systemic candidiasis, histoplasmosis, blastomycosis, coccidioidomycosis, and zygomycosis. However, given the toxicities associated with amphotericin, increasing amphotericin resistance in A. terreus, and the in vitro evidence of superior fungicidal activity of newer azoles, either voriconazole or liposomal amphotericin B are recommended as primary therapy.(41, 58, 104-107) For inadequate responders, recommended salvage therapy consists of caspofungin, micafungin or posaconazole.(58, 106, 108) Antifungal combinations are frequently prescribed for neutropenic patients with suspected mycoses. No consensus exists regarding preferred antifungal combinations, $(58,105)$ though initial strategies combining voriconazole plus caspofungin or amphotericin have been suggested to be superior to single agent therapy in neutropenic patients. $(105,109)$

Antivirals-CMV and HHV-6 lower respiratory tract infections are treated with Ganciclovir or foscarnet. $(41,68,69,110,111)$ The evidence on combining antiviral agents with intravenous immunoglobulin remains inconclusive. $(110,111)$ Even with aggressive therapy, mortality rates remain high with these viral infections.(67) Mortality rates among those with RSV pneumonia approaches $80 \%$, and initiation of treatment with aerosolized ribavirin and intravenous immunoglobulin initiated at the stage of upper respiratory infection is recommended to avoid progression.(70) Intravenous ribavirin has also been used successfully in patients with life-threatening human metapneumovirus disease.(112) Neuraminidase inhibitors, such as oseltamivir, are routinely prescribed for neutropenic patients with documented influenza infections, regardless of whether they have confirmed lung involvement.(25)

\section{Host directed therapies}

Despite broad spectrum antimicrobial strategies, mortality rates remain high in neutropenic patients. These antimicrobial failures arise, at least in part, from the continuing immune defects associated with the neutropenia. Consequently, a number of groups have investigated means by which the immune defects might be restored, allowing pathogen clearance. One focus is correction of the underlying neutropenia. Evidence supports the efficacy of colony stimulating factors, but they are not generally recommended as a treatment for established infection,(25) although in the setting of invasive fungal infections reconstitution of the immune system appears essential for resolution.(58) More recently, transfusion of donor granulocytes and administration of recombinant $\mathrm{T}_{\mathrm{H}} 1$ cytokines have been studied, but this approach, while promising, is still investigational.(113-115) However, some authors argue that severely ill neutropenic patients may benefit from granulocyte transfusion.(116)

A novel alternative strategy to prevent and possibly treat pneumonias in the setting of neutropenia may be induction of innate antimicrobial responses from lung epithelial cells. Lung epithelial cells are long lived and relatively resistant to chemotherapy.(117,118) In addition to their barrier function, recent investigations have demonstrated that these cells also possess the capacity to detect pathogens, to modulate local immune responses, and to generate direct antibacterial responses through the production of antimicrobial peptides and reactive species.(119-123) Advances in the understanding of the molecular mechanisms involved in recognition and signal transduction have allowed development of inhaled 
therapeutics that induce protective innate immune responses from the lung epithelium in animals. In animal models of pneumonia, this provides protection from lethal pathogens even when there is concurrent neutropenic.(124-131) One such treatment, known as PUL-042, is in clinical trials. Preclinical studies demonstrate that in animal models PUL-042 protects against Gram-positive, Gram-negative, fungal and viral pathogen challenges. The real value of this approach is that it offers a new host-directed strategy for combatting infection in the neutropenic cancer patient that can be complementary to traditional antibacterial and antifungal therapeutics.

\section{Conclusion}

Neutropenic pneumonia remains a challenge for the clinician and a threat to the patient. The clinical approach requires integration of traditional microbiologic techniques as well as targeted molecular diagnostics. BAL and serum GM are now more widely available and may be a useful adjunct in select patients, depending on the pre-test probability of IA. It remains uncertain how large an impact GM testing can have, given that the posterior probabilities of disease are often not that different and that empiric treatment is often required. Therapeutic strategies still must rely on early recognition and initiation of broad spectrum antibacterial and antifungal therapy in appropriate patients. New host directed therapies that help to reconstitute the immune system and others that stimulate epithelial innate immunity are under investigation in clinical trials. These may serve to supplement more traditional approaches in the future.

\section{References}

1. File TM. Community-acquired pneumonia. Lancet. 2003; 362(9400):1991-2001. [PubMed: 14683661]

2. Joos L, Tamm M. Breakdown of pulmonary host defense in the immunocompromised host: cancer chemotherapy. Proc Am Thorac Soc. 2005; 2(5):445-8. [PubMed: 16322598]

3. Mizgerd JP. Lung infection--a public health priority. PLoS Med. 2006; 3(2):e76. [PubMed: 16401173]

4. WHO. The World Health Report 2004 -- Changing History. Geneva: World Health Organization; 2004.

5. Ahmed S, Siddiqui AK, Rossoff L, Sison CP, Rai KR. Pulmonary complications in chronic lymphocytic leukemia. Cancer. 2003; 98(9):1912-7. [PubMed: 14584074]

6. Safdar A, Armstrong D. Infectious morbidity in critically ill patients with cancer. Crit Care Clin. 2001; 17(3):531-70. vii-viii. [PubMed: 11525048]

7. Kuderer NM, Dale DC, Crawford J, Cosler LE, Lyman GH. Mortality, morbidity, and cost associated with febrile neutropenia in adult cancer patients. Cancer. 2006; 106(10):2258-66. [PubMed: 16575919]

8. Garcia JB, Lei X, Wierda W, Cortes JE, Dickey BF, Evans SE, et al. Pneumonia during remission induction chemotherapy in patients with acute leukemia. Annals of the American Thoracic Society. 2013; 10(5):432-40. [PubMed: 23987587]

9. Rossini F, Verga M, Pioltelli P, Giltri G, Sancassani V, Pogliani EM, et al. Incidence and outcome of pneumonia in patients with acute leukemia receiving first induction therapy with anthracyclinecontaining regimens. Haematologica. 2000; 85(12):1255-60. [PubMed: 11114131]

10. Specchia G, Pastore D, Carluccio P, Mele G, Montagna MT, Liso A, et al. Pneumonia in acute leukemia patients during induction therapy: experience in a single institution. Leukemia \& lymphoma. 2003; 44(1):97-101. [PubMed: 12691147] 
11. Whimbey E, Goodrich J, Bodey GP. Pneumonia in cancer patients. Cancer Treat Res. 1995; 79:185-210. [PubMed: 8746655]

12. Wilhelm M, Kantarjian HM, O'Brien S, Pierce S, Keating MJ, Freireich EJ, et al. Pneumonia during remission induction chemotherapy in patients with AML or MDS. Leukemia: official journal of the Leukemia Society of America, Leukemia Research Fund, UK. 1996; 10(12):1870-3.

13. Yoshida M, Akiyama N, Fujita H, Miura K, Miyatake J, Handa H, et al. Analysis of bacteremia/ fungemia and pneumonia accompanying acute myelogenous leukemia from 1987 to 2001 in the Japan Adult Leukemia Study Group. International journal of hematology. 2011; 93(1):66-73. [PubMed: 21213127]

14. Cannas G, Pautas C, Raffoux E, Quesnel B, de Botton S, de Revel T, et al. Infectious complications in adult acute myeloid leukemia: analysis of the Acute Leukemia French Association-9802 prospective multicenter clinical trial. Leukemia \& lymphoma. 2012; 53(6): 1068-76. [PubMed: 22145959]

15. Lossos IS, Breuer R, Or R, Strauss N, Elishoov H, Naparstek E, et al. Bacterial pneumonia in recipients of bone marrow transplantation. A five-year prospective study. Transplantation. 1995; 60(7):672-8. [PubMed: 7570975]

16. Roychowdhury M, Pambuccian SE, Aslan DL, Jessurun J, Rose AG, Manivel JC, et al. Pulmonary complications after bone marrow transplantation: an autopsy study from a large transplantation center. Arch Pathol Lab Med. 2005; 129(3):366-71. [PubMed: 15737032]

17. Chang HY, Rodriguez V, Narboni G, Bodey GP, Luna MA, Freireich EJ. Causes of death in adults with acute leukemia. Medicine (Baltimore). 1976; 55(3):259-68. [PubMed: 1063911]

18. Chaoui D, Legrand O, Roche N, Cornet M, Lefebvre A, Peffault de Latour R, et al. Incidence and prognostic value of respiratory events in acute leukemia. Leukemia: official journal of the Leukemia Society of America, Leukemia Research Fund, UK. 2004; 18(4):670-5.

19. Hohenthal U, Itala M, Salonen J, Sipila J, Rantakokko-Jalava K, Meurman O, et al. Bronchoalveolar lavage in immunocompromised patients with haematological malignancy--value of new microbiological methods. Eur J Haematol. 2005; 74(3):203-11. [PubMed: 15693789]

20. Sharma A, Lokeshwar N. Febrile neutropenia in haematological malignancies. J Postgrad Med. 2005; 51 (Suppl 1):S42-8. [PubMed: 16519255]

21. Shorr AF, Susla GM, O'Grady NP. Pulmonary infiltrates in the non-HIV-infected immunocompromised patient: etiologies, diagnostic strategies, and outcomes. Chest. 2004; 125(1): 260-71. [PubMed: 14718449]

22. Peckham D, Elliott MW. Pulmonary infiltrates in the immunocompromised: diagnosis and management. Thorax. 2002; 57(Suppl 2):II3-II7. [PubMed: 12364704]

23. Offidani M, Corvatta L, Malerba L, Marconi M, Leoni P. Infectious complications in adult acute lymphoblastic leukemia (ALL): experience at one single center. Leuk Lymphoma. 2004; 45(8): 1617-21. [PubMed: 15370214]

24. Bodey GP, Buckley M, Sathe YS, Freireich EJ. Quantitative relationships between circulating leukocytes and infection in patients with acute leukemia. Ann Intern Med. 1966; 64(2):328-40. [PubMed: 5216294]

25. Freifeld AG, Bow EJ, Sepkowitz KA, Boeckh MJ, Ito JI, Mullen CA, et al. Clinical practice guideline for the use of antimicrobial agents in neutropenic patients with cancer: 2010 Update by the Infectious Diseases Society of America. Clin Infect Dis. 2011; 52(4):427-31. [PubMed: 21205990]

26. Meyer E, Beyersmann J, Bertz H, Wenzler-Rottele S, Babikir R, Schumacher M, et al. Risk factor analysis of blood stream infection and pneumonia in neutropenic patients after peripheral blood stem-cell transplantation. Bone marrow transplantation. 2007; 39(3):173-8. [PubMed: 17245425]

27. Lanoix JP, Schmit JL, Douadi Y. Bacterial lung sepsis in patients with febrile neutropenia. Current opinion in pulmonary medicine. 2012; 18(3):175-80. [PubMed: 22343426]

28. Lyman GH, Delgado DJ. Risk and timing of hospitalization for febrile neutropenia in patients receiving CHOP, CHOP-R, or CNOP chemotherapy for intermediate-grade non-Hodgkin lymphoma. Cancer. 2003; 98(11):2402-9. [PubMed: 14635075] 
29. Lyman GH, Morrison VA, Dale DC, Crawford J, Delgado DJ, Fridman M. Risk of febrile neutropenia among patients with intermediate-grade non-Hodgkin's lymphoma receiving CHOP chemotherapy. Leuk Lymphoma. 2003; 44(12):2069-76. [PubMed: 14959849]

30. Lynn JJ, Chen KF, Weng YM, Chiu TF. Risk factors associated with complications in patients with chemotherapy-induced febrile neutropenia in emergency department. Hematological oncology. 2013; 31(4):189-96. [PubMed: 23303687]

31. Hubel K, Hegener K, Schnell R, Mansmann G, Oberhauser F, Staib P, et al. Suppressed neutrophil function as a risk factor for severe infection after cytotoxic chemotherapy in patients with acute nonlymphocytic leukemia. Ann Hematol. 1999; 78(2):73-7. [PubMed: 10089021]

32. Mandell LA, Wunderink RG, Anzueto A, Bartlett JG, Campbell GD, Dean NC, et al. Infectious Diseases Society of America/American Thoracic Society consensus guidelines on the management of community-acquired pneumonia in adults. Clin Infect Dis. 2007; 44 (Suppl 2):S27-72. [PubMed: 17278083]

33. Niederman MS, Mandell LA, Anzueto A, Bass JB, Broughton WA, Campbell GD, et al. Guidelines for the management of adults with community-acquired pneumonia. Diagnosis, assessment of severity, antimicrobial therapy, and prevention. Am J Respir Crit Care Med. 2001; 163(7):1730-54. [PubMed: 11401897]

34. BTS Guidelines for the Management of Community Acquired Pneumonia in Adults. Thorax. 2001; 56(Suppl 4):IV1-64. [PubMed: 11713364]

*35. Gonzalez C, Johnson T, Rolston K, Merriman K, Warneke C, Evans S. Predicting pneumonia mortality using CURB-65, PSI, and patient characteristics in patients presenting to the emergency department of a comprehensive cancer center. Cancer medicine. 2014; 3(4):962-70. This paper assesses the outcomes of cancer patients when attempting to apply clinical management strategies that were developed for non-cancer, community dwelling populations, underscoring the important differences between these populations. [PubMed: 24802800]

36. Bartlett JG. Community-acquired pneumonia. International journal of clinical practice Supplement. 2000; (115):18-22. [PubMed: 11219294]

37. Bartlett JG, Dowell SF, Mandell LA, File TM Jr, Musher DM, Fine MJ. Practice guidelines for the management of community-acquired pneumonia in adults. Infectious Diseases Society of America. Clin Infect Dis. 2000; 31(2):347-82. [PubMed: 10987697]

38. Aisenberg G, Rolston KV, Safdar A. Bacteremia caused by Achromobacter and Alcaligenes species in 46 patients with cancer (1989-2003). Cancer. 2004; 101(9):2134-40. [PubMed: 15389476]

39. Safdar A, Rolston KV. Stenotrophomonas maltophilia: changing spectrum of a serious bacterial pathogen in patients with cancer. Clin Infect Dis. 2007; 45(12):1602-9. [PubMed: 18190323]

40. Klastersky J, Aoun M. Opportunistic infections in patients with cancer. Annals of oncology: official journal of the European Society for Medical Oncology/ESMO. 2004; 15(Suppl 4):iv32935. [PubMed: 15477331]

*41. Maschmeyer G, Carratala J, Buchheidt D, Hamprecht A, Heussel CP, Kahl C, et al. Diagnosis and antimicrobial therapy of lung infiltrates in febrile neutropenic patients (allogeneic SCT excluded): updated guidelines of the Infectious Diseases Working Party (AGIHO) of the German Society of Hematology and Medical Oncology (DGHO)dagger. Annals of oncology: official journal of the European Society for Medical Oncology/ESMO. 2014 This is the most recent guideline published regarding the management of neutropenic fever, providing practical guideance prior to pathogen identification.

42. Einsele H, Bertz H, Beyer J, Kiehl MG, Runde V, Kolb HJ, et al. Infectious complications after allogeneic stem cell transplantation: epidemiology and interventional therapy strategies-guidelines of the Infectious Diseases Working Party (AGIHO) of the German Society of Hematology and Oncology (DGHO). Ann Hematol. 2003; 82 (Suppl 2):S175-85. [PubMed: 13680165]

43. Gudiol C, Bodro M, Simonetti A, Tubau F, Gonzalez-Barca E, Cisnal M, et al. Changing aetiology, clinical features, antimicrobial resistance, and outcomes of bloodstream infection in neutropenic cancer patients. Clin Microbiol Infect. 2013; 19(5):474-9. [PubMed: 22524597]

44. Marchetti O, Calandra T. Infections in neutropenic cancer patients. Lancet. 2002; 359(9308):7235. [PubMed: 11888579] 
45. Maschmeyer G. Diagnosis and antimicrobial therapy of lung infiltrates in febrile neutropenic cancer patients. Curr Infect Dis Rep. 2011; 13(6):510-6. [PubMed: 21956704]

46. Mandell LA, Bartlett JG, Dowell SF, File TM Jr, Musher DM, Whitney C. Update of practice guidelines for the management of community-acquired pneumonia in immunocompetent adults. Clin Infect Dis. 2003; 37(11):1405-33. [PubMed: 14614663]

$* * 47$. Guidelines for the management of adults with hospital-acquired, ventilator-associated, and healthcare-associated pneumonia. Am J Respir Crit Care Med. 2005; 171(4):388-416. This statement from the ATS and IDSA is the most widely cited guideline for management of nosocomally acquired pneumonias, and is highly relevant as most neutropenic pneumonias among cancer patients are acquired in the healthcare setting. [PubMed: 15699079]

48. El-Solh AA, Aquilina AT, Dhillon RS, Ramadan F, Nowak P, Davies J. Impact of invasive strategy on management of antimicrobial treatment failure in institutionalized older people with severe pneumonia. Am J Respir Crit Care Med. 2002; 166(8):1038-43. [PubMed: 12379545]

49. Araoka H, Fujii T, Izutsu K, Kimura M, Nishida A, Ishiwata K, et al. Rapidly progressive fatal hemorrhagic pneumonia caused by Stenotrophomonas maltophilia in hematologic malignancy. Transplant infectious disease: an official journal of the Transplantation Society. 2012; 14(4):35563. [PubMed: 22283869]

50. Duncan MD, Wilkes DS. Transplant-related immunosuppression: a review of immunosuppression and pulmonary infections. Proc Am Thorac Soc. 2005; 2(5):449-55. [PubMed: 16322599]

51. Yadegarynia D, Tarrand J, Raad I, KR. Current spectrum of bacterial infections in patients with cancer. Clin Infect Dis. 2003; 37(8):1144-5. [PubMed: 14523785]

52. Mori M, Tsunemine H, Imada K, Ito K, Kodaka T, Takahashi T. Life-threatening hemorrhagic pneumonia caused by Stenotrophomonas maltophilia in the treatment of hematologic diseases. Ann Hematol. 2014; 93(6):901-11. [PubMed: 24535696]

53. Rello J, Ollendorf DA, Oster G, Vera-Llonch M, Bellm L, Redman R, et al. Epidemiology and outcomes of ventilator-associated pneumonia in a large US database. Chest. 2002; 122(6):211521. [PubMed: 12475855]

54. Harrington RD, Woolfrey AE, Bowden R, McDowell MG, Hackman RC. Legionellosis in a bone marrow transplant center. Bone marrow transplantation. 1996; 18(2):361-8. [PubMed: 8864447]

55. Kugler JW, Armitage JO, Helms CM, Klassen LW, Goeken NE, Ahmann GB, et al. Nosocomial Legionnaires' disease. Occurrence in recipients of bone marrow transplants. Am J Med. 1983; 74(2):281-8. [PubMed: 6337488]

56. Torres HA, Reddy BT, Raad II, Tarrand J, Bodey GP, Hanna HA, et al. Nocardiosis in cancer patients. Medicine (Baltimore). 2002; 81(5):388-97. [PubMed: 12352633]

57. Hachem RY, Kontoyiannis DP, Boktour MR, Afif C, Cooksley C, Bodey GP, et al. Aspergillus terreus: an emerging amphotericin B-resistant opportunistic mold in patients with hematologic malignancies. Cancer. 2004; 101(7):1594-600. [PubMed: 15378491]

**58. Limper AH, Knox KS, Sarosi GA, Ampel NM, Bennett JE, Catanzaro A, et al. An official American Thoracic Society statement: Treatment of fungal infections in adult pulmonary and critical care patients. Am J Respir Crit Care Med. 2011; 183(1):96-128. This statement from the ATS provides essential background on management of fungal infections and practical guideance for antifunfal therapy. [PubMed: 21193785]

59. Marr KA, Carter RA, Boeckh M, Martin P, Corey L. Invasive aspergillosis in allogeneic stem cell transplant recipients: changes in epidemiology and risk factors. Blood. 2002; 100(13):4358-66. [PubMed: 12393425]

60. Marr KA, Carter RA, Crippa F, Wald A, Corey L. Epidemiology and outcome of mould infections in hematopoietic stem cell transplant recipients. Clin Infect Dis. 2002; 34(7):909-17. [PubMed: 11880955]

61. Marr KA, Patterson T, Denning D. Aspergillosis. Pathogenesis, clinical manifestations, and therapy. Infect Dis Clin North Am. 2002; 16(4):875-94. vi. [PubMed: 12512185]

62. Mulanovich VE, Kontoyiannis DP. Fungal pneumonia in patients with hematologic malignancies: current approach and management. Curr Opin Infect Dis. 2011; 24(4):323-32. [PubMed: 21666457] 
63. Kontoyiannis DP, Lionakis MS, Lewis RE, Chamilos G, Healy M, Perego C, et al. Zygomycosis in a tertiary-care cancer center in the era of Aspergillus-active antifungal therapy: a case-control observational study of 27 recent cases. J Infect Dis. 2005; 191(8):1350-60. [PubMed: 15776383]

64. Roblot F, Le Moal G, Godet C, Hutin P, Texereau M, Boyer E, et al. Pneumocystis carinii pneumonia in patients with hematologic malignancies: a descriptive study. The Journal of infection. 2003; 47(1):19-27. [PubMed: 12850158]

65. Thomas CF Jr, Limper AH. Pneumocystis pneumonia. N Engl J Med. 2004; 350(24):2487-98. [PubMed: 15190141]

66. Souza JP, Boeckh M, Gooley TA, Flowers ME, Crawford SW. High rates of Pneumocystis carinii pneumonia in allogeneic blood and marrow transplant recipients receiving dapsone prophylaxis. Clin Infect Dis. 1999; 29(6):1467-71. [PubMed: 10585797]

67. Konoplev S, Champlin RE, Giralt S, Ueno NT, Khouri I, Raad I, et al. Cytomegalovirus pneumonia in adult autologous blood and marrow transplant recipients. Bone marrow transplantation. 2001; 27(8):877-81. [PubMed: 11477447]

68. Nguyen Q, Champlin R, Giralt S, Rolston K, Raad I, Jacobson K, et al. Late cytomegalovirus pneumonia in adult allogeneic blood and marrow transplant recipients. Clin Infect Dis. 1999; 28(3):618-23. [PubMed: 10194088]

69. Atkinson K, Nivison-Smith I, Dodds A, Concannon A, Milliken S, Downs K. A comparison of the pattern of interstitial pneumonitis following allogeneic bone marrow transplantation before and after the introduction of prophylactic ganciclovir therapy in 1989. Bone marrow transplantation. 1998; 21(7):691-5. [PubMed: 9578309]

70. Ghosh S, Champlin RE, Ueno NT, Anderlini P, Rolston K, Raad I, et al. Respiratory syncytial virus infections in autologous blood and marrow transplant recipients with breast cancer: combination therapy with aerosolized ribavirin and parenteral immunoglobulins. Bone marrow transplantation. 2001; 28(3):271-5. [PubMed: 11535995]

71. De La Rosa GR, Jacobson KL, Rolston KV, Raad II, Kontoyiannis DP, Safdar A. Mycobacterium tuberculosis at a comprehensive cancer centre: active disease in patients with underlying malignancy during 1990-2000. Clin Microbiol Infect. 2004; 10(8):749-52. [PubMed: 15301678]

72. Weinstock DM, Feinstein MB, Sepkowitz KA, Jakubowski A. High rates of infection and colonization by nontuberculous mycobacteria after allogeneic hematopoietic stem cell transplantation. Bone marrow transplantation. 2003; 31(11):1015-21. [PubMed: 12774053]

73. Rolston KV, Bodey GP, Safdar A. Polymicrobial infection in patients with cancer: an underappreciated and underreported entity. Clin Infect Dis. 2007; 45(2):228-33. [PubMed: 17578784]

74. Rano A, Agusti C, Jimenez P, Angrill J, Benito N, Danes C, et al. Pulmonary infiltrates in nonHIV immunocompromised patients: a diagnostic approach using non-invasive and bronchoscopic procedures. Thorax. 2001; 56(5):379-87. [PubMed: 11312407]

75. Wahla AS, Chatterjee A, Khan II, Conforti JF, Haponik E. Survey of academic pulmonologists, oncologists, and infectious disease physicians on the role of bronchoscopy in managing hematopoietic stem cell transplantation patients with pulmonary infiltrates. Journal of bronchology \& interventional pulmonology. 2014; 21(1):32-9. [PubMed: 24419184]

76. Sampsonas F, Kontoyiannis DP, Dickey BF, Evans SE. Performance of a standardized bronchoalveolar lavage protocol in a comprehensive cancer center: A Prospective 2-Year Study. Cancer. 2011

77. Hohenadel IA, Kiworr M, Genitsariotis R, Zeidler D, Lorenz J. Role of bronchoalveolar lavage in immunocompromised patients with pneumonia treated with a broad spectrum antibiotic and antifungal regimen. Thorax. 2001; 56(2):115-20. [PubMed: 11209099]

78. Rano A, Agusti C, Sibila O, Torres A. Pulmonary infections in non-HIV-immunocompromised patients. Current opinion in pulmonary medicine. 2005; 11(3):213-7. [PubMed: 15818182]

79. White P, Bonacum JT, Miller CB. Utility of fiberoptic bronchoscopy in bone marrow transplant patients. Bone marrow transplantation. 1997; 20(8):681-7. [PubMed: 9383232]

80. Shannon VR, Andersson BS, Lei X, Champlin RE, Kontoyiannis DP. Utility of early versus late fiberoptic bronchoscopy in the evaluation of new pulmonary infiltrates following hematopoietic stem cell transplantation. Bone marrow transplantation. 2010; 45(4):647-55. [PubMed: 19684637] 
81. Chen SC, Kontoyiannis DP. New molecular and surrogate biomarker-based tests in the diagnosis of bacterial and fungal infection in febrile neutropenic patients. Curr Opin Infect Dis. 2010; 23(6): 567-77. [PubMed: 20827189]

82. Maschmeyer G, Haas A, Cornely OA. Invasive aspergillosis: epidemiology, diagnosis and management in immunocompromised patients. Drugs. 2007; 67(11):1567-601. [PubMed: 17661528]

83. Rodloff C, Koch D, Schaumann R. Epidemiology and antifungal resistance in invasive candidiasis. Eur J Med Res. 2011; 16(4):187-95. [PubMed: 21486733]

*84. Affolter K, Tamm M, Jahn K, Halter J, Passweg J, Hirsch HH, et al. Galactomannan in bronchoalveolar lavage for diagnosing invasive fungal disease. Am J Respir Crit Care Med. 2014; 190(3):309-17. This is an important recent advance in the assessment of BAL assays for galactomannan as a tool to identify invasive fungal infections. [PubMed: 25007380]

85. Cuenca-Estrella M, Bassetti M, Lass-Florl C, Racil Z, Richardson M, Rogers TR. Detection and investigation of invasive mould disease. The Journal of antimicrobial chemotherapy. 2011; 66 (Suppl 1):i15-24. [PubMed: 21177400]

86. Kontoyiannis DP, Marr KA, Park BJ, Alexander BD, Anaissie EJ, Walsh TJ, et al. Prospective surveillance for invasive fungal infections in hematopoietic stem cell transplant recipients, 20012006: overview of the Transplant-Associated Infection Surveillance Network (TRANSNET) Database. Clin Infect Dis. 2010; 50(8):1091-100. [PubMed: 20218877]

87. Neofytos D, Horn D, Anaissie E, Steinbach W, Olyaei A, Fishman J, et al. Epidemiology and outcome of invasive fungal infection in adult hematopoietic stem cell transplant recipients: analysis of Multicenter Prospective Antifungal Therapy (PATH) Alliance registry. Clin Infect Dis. 2009; 48(3):265-73. [PubMed: 19115967]

88. Maertens J, Theunissen K, Lodewyck T, Lagrou K, Van Eldere J. Advances in the serological diagnosis of invasive Aspergillus infections in patients with haematological disorders. Mycoses. 2007; 50 (Suppl 1):2-17. [PubMed: 17394605]

89. Zedek DC, Miller MB. Use of galactomannan enzyme immunoassay for diagnosis of invasive aspergillosis in a tertiary-care center over a 12-month period. Journal of clinical microbiology. 2006; 44(4):1601. [PubMed: 16597909]

90. Hope WW, Walsh TJ, Denning DW. Laboratory diagnosis of invasive aspergillosis. The Lancet Infectious diseases. 2005; 5(10):609-22. [PubMed: 16183515]

91. Tortorano AM, Esposto MC, Prigitano A, Grancini A, Ossi C, Cavanna C, et al. Cross-reactivity of Fusarium spp. in the Aspergillus Galactomannan enzyme-linked immunosorbent assay. Journal of clinical microbiology. 2012; 50(3):1051-3. [PubMed: 22205818]

92. Huang YT, Hung CC, Hsueh PR. Aspergillus galactomannan antigenemia in penicilliosis marneffei. Aids. 2007; 21(14):1990-1. [PubMed: 17721116]

93. Wheat LJ, Hackett E, Durkin M, Connolly P, Petraitiene R, Walsh TJ, et al. Histoplasmosisassociated cross-reactivity in the BioRad Platelia Aspergillus enzyme immunoassay. Clinical and vaccine immunology: CVI. 2007; 14(5):638-40. [PubMed: 17344352]

94. Walsh TJ, Shoham S, Petraitiene R, Sein T, Schaufele R, Kelaher A, et al. Detection of galactomannan antigenemia in patients receiving piperacillin-tazobactam and correlations between in vitro, in vivo, and clinical properties of the drug-antigen interaction. Journal of clinical microbiology. 2004; 42(10):4744-8. [PubMed: 15472335]

95. Vergidis P, Razonable RR, Wheat LJ, Estes L, Caliendo AM, Baden LR, et al. Reduction in falsepositive Aspergillus serum galactomannan enzyme immunoassay results associated with use of piperacillin-tazobactam in the United States. Journal of clinical microbiology. 2014; 52(6):2199201. [PubMed: 24719434]

96. Ascioglu S, Rex JH, de Pauw B, Bennett JE, Bille J, Crokaert F, et al. Defining opportunistic invasive fungal infections in immunocompromised patients with cancer and hematopoietic stem cell transplants: an international consensus. Clin Infect Dis. 2002; 34(1):7-14. [PubMed: 11731939]

97. De Pauw B, Walsh TJ, Donnelly JP, Stevens DA, Edwards JE, Calandra T, et al. Revised definitions of invasive fungal disease from the European Organization for Research and Treatment of Cancer/Invasive Fungal Infections Cooperative Group and the National Institute of Allergy and 
Infectious Diseases Mycoses Study Group (EORTC/MSG) Consensus Group. Clin Infect Dis. 2008; 46(12):1813-21. [PubMed: 18462102]

98. Zou M, Tang L, Zhao S, Zhao Z, Chen L, Chen P, et al. Systematic review and meta-analysis of detecting galactomannan in bronchoalveolar lavage fluid for diagnosing invasive aspergillosis. PloS one. 2012; 7(8):e43347. [PubMed: 22905261]

99. D’Haese J, Theunissen K, Vermeulen E, Schoemans H, De Vlieger G, Lammertijn L, et al. Detection of galactomannan in bronchoalveolar lavage fluid samples of patients at risk for invasive pulmonary aspergillosis: analytical and clinical validity. Journal of clinical microbiology. 2012; 50(4):1258-63. [PubMed: 22301025]

100. Pfeiffer CD, Fine JP, Safdar N. Diagnosis of invasive aspergillosis using a galactomannan assay: a meta-analysis. Clin Infect Dis. 2006; 42(10):1417-27. [PubMed: 16619154]

101. Ibrahim EH, Sherman G, Ward S, Fraser VJ, Kollef MH. The influence of inadequate antimicrobial treatment of bloodstream infections on patient outcomes in the ICU setting. Chest. 2000; 118(1):146-55. [PubMed: 10893372]

*102. Weissinger F, Auner HW, Bertz H, Buchheidt D, Cornely OA, Egerer G, et al. Antimicrobial therapy of febrile complications after high-dose chemotherapy and autologous hematopoietic stem cell transplantation--guidelines of the Infectious Diseases Working Party (AGIHO) of the German Society of Hematology and Oncology (DGHO). Ann Hematol. 2012; 91(8):1161-74. This recent statement from the DGHO provides recent guidelines for management of febrile neutropenia in the focus population of the current review, cancer patients with neutropenia. [PubMed: 22638755]

103. von Eiff M, Roos N, Schulten R, Hesse M, Zuhlsdorf M, van de Loo J. Pulmonary aspergillosis: early diagnosis improves survival. Respiration. 1995; 62(6):341-7. [PubMed: 8552866]

104. Herbrecht R, Denning DW, Patterson TF, Bennett JE, Greene RE, Oestmann JW, et al. Voriconazole versus amphotericin B for primary therapy of invasive aspergillosis. N Engl J Med. 2002; 347(6):408-15. [PubMed: 12167683]

*105. Mousset S, Buchheidt D, Heinz W, Ruhnke M, Cornely OA, Egerer G, et al. Treatment of invasive fungal infections in cancer patients-updated recommendations of the Infectious Diseases Working Party (AGIHO) of the German Society of Hematology and Oncology (DGHO). Ann Hematol. 2014; 93(1):13-32. This statement from the DGHO provides similar, but contrasted, recommendations for management of invasive fungal infections and highlights specific management the cancer population. [PubMed: 24026426]

106. Walsh TJ, Anaissie EJ, Denning DW, Herbrecht R, Kontoyiannis DP, Marr KA, et al. Treatment of aspergillosis: clinical practice guidelines of the Infectious Diseases Society of America. Clin Infect Dis. 2008; 46(3):327-60. [PubMed: 18177225]

107. Chamilos G, Kontoyiannis DP. Update on antifungal drug resistance mechanisms of Aspergillus fumigatus. Drug resistance updates: reviews and commentaries in antimicrobial and anticancer chemotherapy. 2005; 8(6):344-58. [PubMed: 16488654]

108. Maertens J, Raad I, Petrikkos G, Boogaerts M, Selleslag D, Petersen FB, et al. Efficacy and safety of caspofungin for treatment of invasive aspergillosis in patients refractory to or intolerant of conventional antifungal therapy. Clin Infect Dis. 2004; 39(11):1563-71. [PubMed: 15578352]

109. Marr K. Combination antifungal therapy: where are we now, and where are we going? Oncology (Huntingt). 2004; 18(13 Suppl 7):24-9. [PubMed: 15651179]

110. Reed E, Bowden R, Dandliker P, Lilleby K, Meyers J. Treatment of cytomegalovirus pneumonia with ganciclovir and intravenous cytomegalovirus immunoglobulin in patients with bone marrow transplants. Ann Intern Med. 1988; 109:783-8. [PubMed: 2847610]

111. Emanuel D, Cunningham I, Jules-Elysee K, Brochstein JA, Kernan NA, Laver J, et al. Cytomegalovirus pneumonia after bone marrow transplantation successfully treated with the combination of ganciclovir and high-dose intravenous immune globulin. Ann Intern Med. 1988; 109(10):777-82. [PubMed: 2847609]

112. Safdar A. Immune modulatory activity of ribavirin for serious human metapneumovirus disease: early i.v. therapy may improve outcomes in immunosuppressed SCT recipients. Bone marrow transplantation. 2008; 41(8):707-8. [PubMed: 18347567] 
113. Safdar A, Hanna HA, Boktour M, Kontoyiannis DP, Hachem R, Lichtiger B, et al. Impact of high-dose granulocyte transfusions in patients with cancer with candidemia: retrospective casecontrol analysis of 491 episodes of Candida species bloodstream infections. Cancer. 2004; 101(12):2859-65. [PubMed: 15529309]

114. Safdar A, Rodriguez G, Ohmagari N, Kontoyiannis DP, Rolston KV, Raad II, et al. The safety of interferon-gamma-1b therapy for invasive fungal infections after hematopoietic stem cell transplantation. Cancer. 2005; 103(4):731-9. [PubMed: 15641032]

115. Safdar A, Rodriguez GH, Lichtiger B, Dickey BF, Kontoyiannis DP, Freireich EJ, et al. Recombinant interferon gammalb immune enhancement in 20 patients with hematologic malignancies and systemic opportunistic infections treated with donor granulocyte transfusions. Cancer. 2006; 106(12):2664-71. [PubMed: 16691620]

116. Cherif H, Axdorph U, Kalin M, Bjorkholm M. Clinical experience of granulocyte transfusion in the management of neutropenic patients with haematological malignancies and severe infection. Scandinavian journal of infectious diseases. 2013; 45(2):112-6. [PubMed: 22992038]

117. Bowden DH. Cell turnover in the lung. The American review of respiratory disease. $1983 ; 128(2$ Pt 2):S46-8. [PubMed: 6881708]

118. Rawlins EL, Hogan BL. Ciliated epithelial cell lifespan in the mouse trachea and lung. American journal of physiology Lung cellular and molecular physiology. 2008; 295(1):L231-4. [PubMed: 18487354]

119. Bals R, Hiemstra PS. Innate immunity in the lung: how epithelial cells fight against respiratory pathogens. Eur Respir J. 2004; 23(2):327-33. [PubMed: 14979512]

120. Bartlett JA, Fischer AJ, McCray PB Jr. Innate immune functions of the airway epithelium. Contrib Microbiol. 2008; 15:147-63. [PubMed: 18511860]

121. Hippenstiel S, Opitz B, Schmeck B, Suttorp N. Lung epithelium as a sentinel and effector system in pneumonia--molecular mechanisms of pathogen recognition and signal transduction. Respir Res. 2006; 7:97. [PubMed: 16827942]

122. Mayer AK, Bartz H, Fey F, Schmidt LM, Dalpke AH. Airway epithelial cells modify immune responses by inducing an anti-inflammatory microenvironment. European journal of immunology. 2008; 38(6):1689-99. [PubMed: 18421791]

123. Mayer AK, Dalpke AH. Regulation of local immunity by airway epithelial cells. Archivum immunologiae et therapiae experimentalis. 2007; 55(6):353-62. [PubMed: 18060372]

*124. Cleaver JO, You D, Michaud DR, Guzman Pruneda FA, Leiva Juarez MM, Zhang J, et al. Lung epithelial cells are essential effectors of inducible resistance to pneumonia. Mucosal Immunol. 2014; 7(1):78-88. This paper demonstrates the capacity of lung epithelial cells to contribute significantly to the antimicrobial response, and suggests that epithelial responses may be manipulated to protect neutropenic cancer patients. [PubMed: 23632328]

125. Clement CG, Evans SE, Evans CM, Hawke D, Kobayashi R, Reynolds PR, et al. Stimulation of lung innate immunity protects against lethal pneumococcal pneumonia in mice. Am J Respir Crit Care Med. 2008; 177(12):1322-30. [PubMed: 18388354]

126. Duggan JM, You D, Cleaver JO, Larson DT, Garza RJ, Guzman Pruneda FA, et al. Synergistic interactions of TLR2/6 and TLR9 induce a high level of resistance to lung infection in mice. J Immunol. 2011; 186(10):5916-26. [PubMed: 21482737]

127. Evans SE, Scott BL, Clement CG, Larson DT, Kontoyiannis D, Lewis RE, et al. Stimulated innate resistance of lung epithelium protects mice broadly against bacteria and fungi. Am J Respir Cell Mol Biol. 2010; 42(1):40-50. [PubMed: 19329554]

128. Evans SE, Tuvim MJ, Fox CJ, Sachdev N, Gibiansky L, Dickey BF. Inhaled innate immune ligands to prevent pneumonia. British journal of pharmacology. 2011; 163(1):195-206. [PubMed: 21250981]

129. Evans SE, Xu Y, Tuvim MJ, Dickey BF. Inducible innate resistance of lung epithelium to infection. Annu Rev Physiol. 2010; 72:413-35. [PubMed: 20148683]

130. Moron CG, Tuvim MJ, Evans CM, Dickey BF. Stimulation of innate immune defense protects against S. pneumoniae infection. Proc Am Thorac Soc. 2005; 2:A452. (abstract).

131. Tuvim MJ, Gilbert BE, Dickey BF, Evans SE. Synergistic TLR2/6 and TLR9 activation protects mice against lethal influenza pneumonia. PLoS ONE. 2012; 7(1):e30596. [PubMed: 22299046] 


\section{Key Points}

- Pneumonia in the cancer patient accounts for more morbidity and mortality than any other complication.

- Initial broad spectrum antibacterial coverage including resistant gram negatives and MRSA is warranted in high risk neutropenic cancer patients, with antifungals for those that have persistent fevers or risk factors.

- Serum and BAL GM testing is now more widely available for clinical use and may be beneficial in select patients with neutropenic fever and suspicion of pneumonia.

- Host directed therapies that enhance innate epithelial immunity and that reconstitute the immune system are undergoing clinical investigation. 

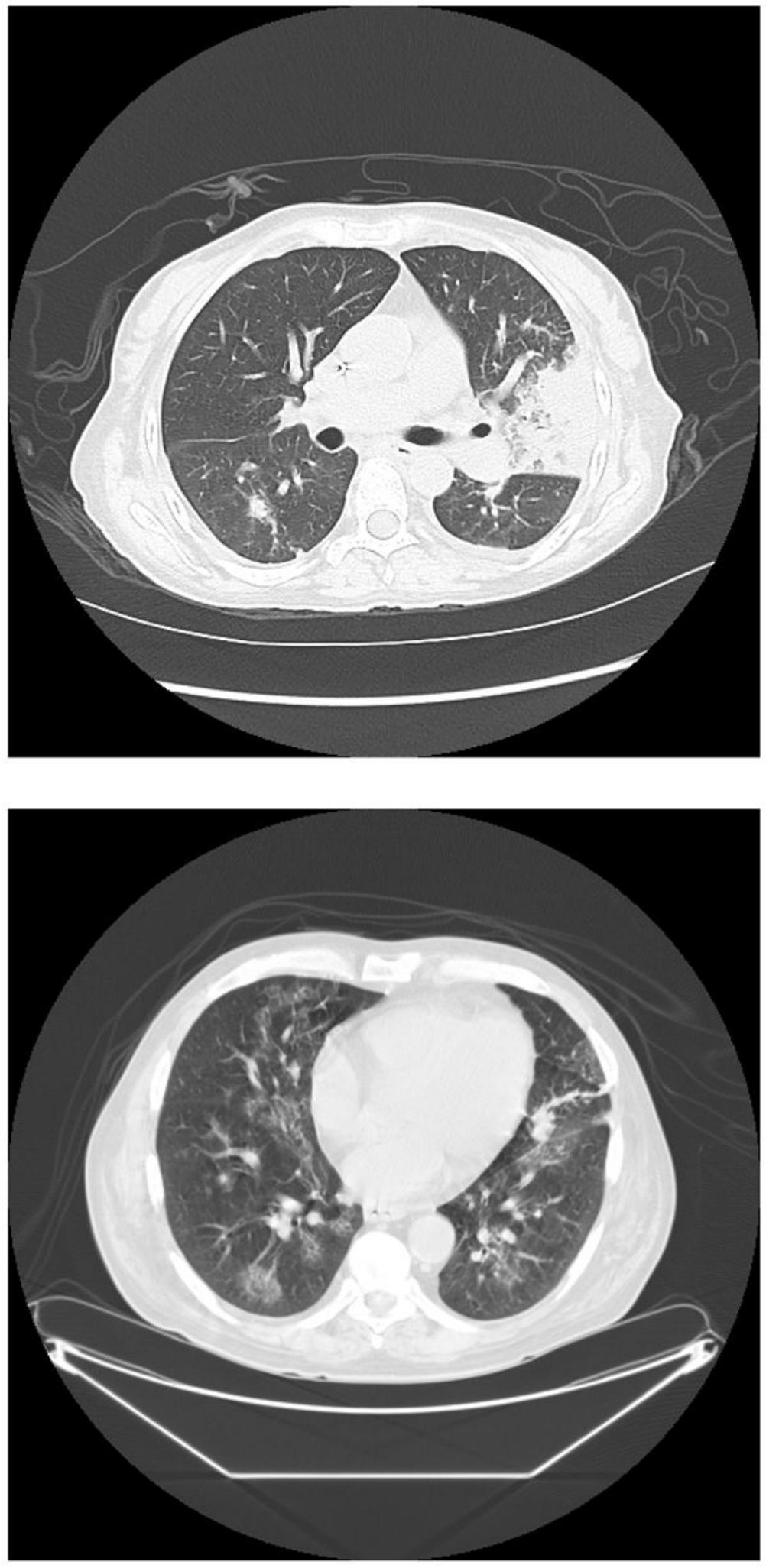

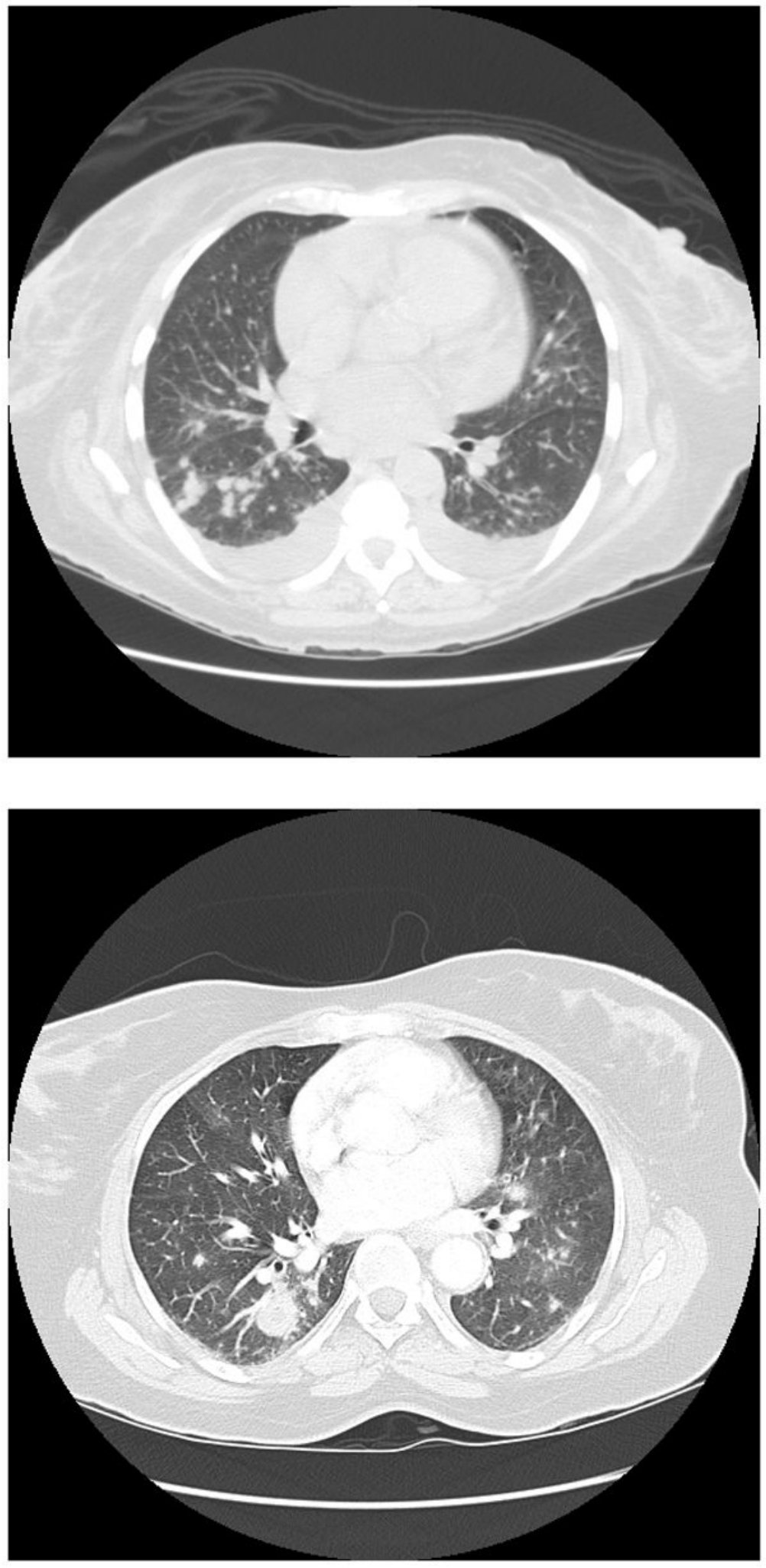

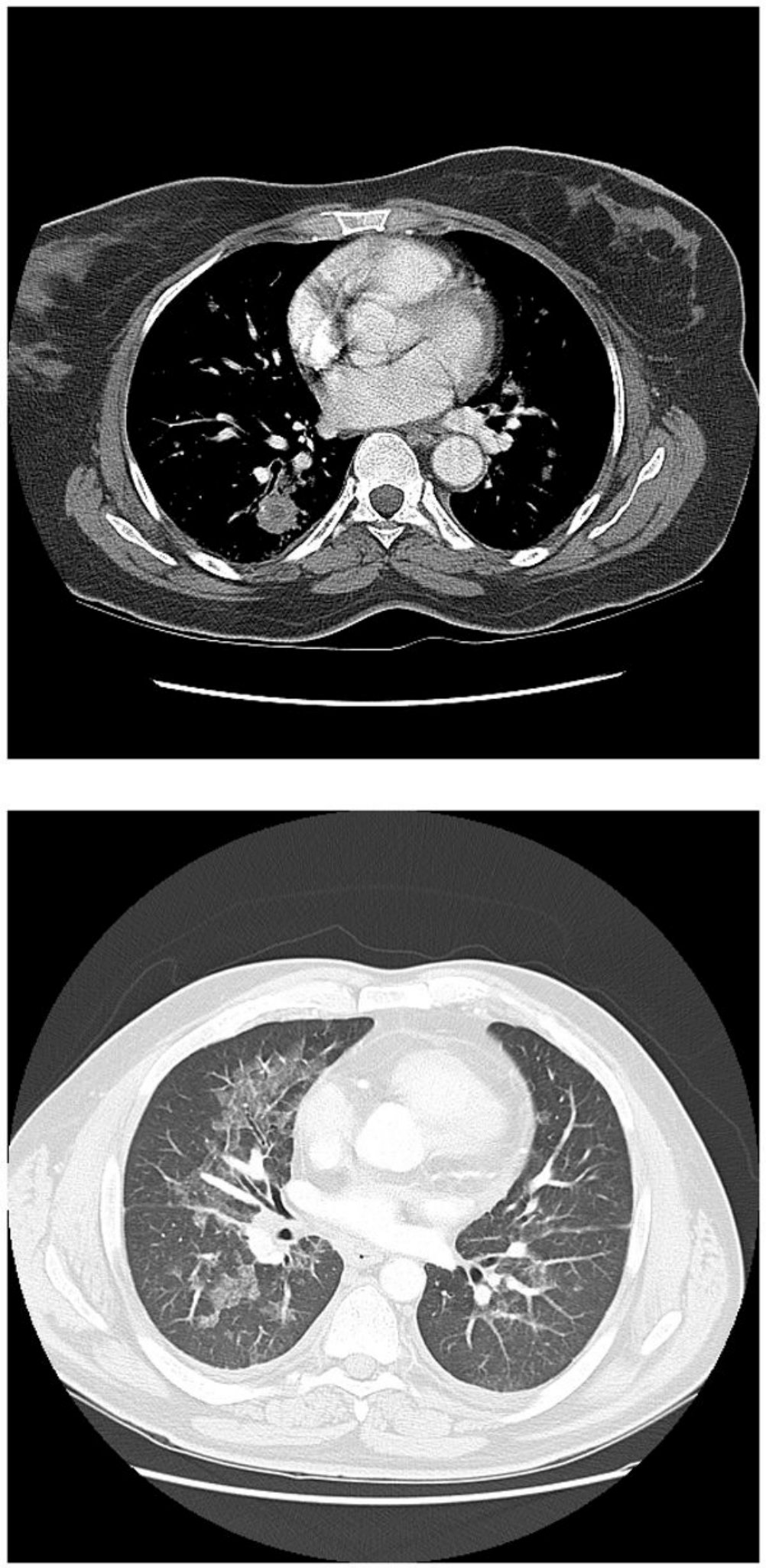

Figure 1. 
Figure 1a. 50 year old woman with relapsed refractory B-cell lymphoma, neutropenic, with fevers, presenting with consolidation in the lingula. Galactomannan index was 1.98.

Figure 1b. 60 year old man with history of Hodgkins lymphoma with autologous bone marrow transplant, 3 years later developed myelodysplastic syndrome with progression to acute myeloid leukemia, presented with neutropenic fevers following. Nodular and ground glass opacities are present bilaterally. BALF was positive for Aspergillus.

Figure 1c. 68 year old woman with acute myeloid leukemia with neutropenia after induction chemotherapy. Numerous bilateral pulmonary nodules were seen, most prominent in the RLL superior segment. BALF was positive for aspergillus.

Figure 1d. 50 year old woman with acute myeloid leukemia, received induction chemotherapy, had prolonged neutropenia, and developed fevers with bilateral nodular and ground glass opacities. Note the largest nodular density in the right lower lobe has a central low atenuation zone consistent with necrosis. This is seen more easily in the righ thand panel.

Figure 1e. 54 year old man who presented with fevers and ground glass opacities to his local physician. After he failed to respond to antibiotics he was admitted to a local hospital and diagnosed with acute myeloid leukemia. He was transferred to receive induction chemotherapy. At the time of presentation patient had bilateral ground glass opacities as shown above, BAL was positive for Aspergillus. 


\section{Table 1}

Pathogens of special concern in neutropenic pneumonia.

\begin{tabular}{|c|c|c|}
\hline Gram positive bacteria & Gram negative bacteria & Viruses \\
\hline Streptococcus pneumoniae & Pseudomonas spp.* & Influenza $\mathrm{A} / \mathrm{B}$ viruses \\
\hline Streptococcus pyogenes & Klebsiella pneumonia* & Parainfluenza $1-3$ viruses \\
\hline Staphylococcus aureus ${ }^{*}$ & Escherichia coli $^{*}$ & Human metapneumovirus \\
\hline Nocardia spp. & Enterobacter cloacae ${ }^{*}$ & Adenoviruses \\
\hline \multirow[t]{2}{*}{ Rhodococcus equi } & Stenotrophomonas maltophilia ${ }^{*}$ & Cytomegalovirus \\
\hline & Citrobacter spp. ${ }^{*}$ & Respiratory syncytial virus \\
\hline Fungi & Serretia marcescens ${ }^{*}$ & Varicella-zoster virus \\
\hline Aspergillus spp. ${ }^{*}$ & Acinetobacter baumannii-complex & Human herpes virus 6 \\
\hline Fusarium spp. & Nontypeable Hemophilus influenza & \\
\hline Pseudaalesheria boydii & Proteus spp. ${ }^{*}$ & Mycobacteria \\
\hline Scedosporium spp. & Burkholderia spp. & Mycobacterium tuberculosis \\
\hline Histoplasma capsulatum & Chryseobacterium meningosepticum & Nontubercuous mycobacteria \\
\hline Blastomycetes dermatitidis & Alcaligenes/Achromobacter spp. & \\
\hline Coccidioides immitis & Neisseria meningitides & Atypical organisms \\
\hline Mucor spp. ${ }^{*}$ & Moraxella catarrhalis & Mycoplasma pneumoniae \\
\hline Rhizopus spp. ${ }^{*}$ & & Chlamydophyla pneumoniae \\
\hline Pneumocystis jiroveci & & Legionella $\mathrm{spp}$ \\
\hline
\end{tabular}

particular risk for antimicrobial resistance, depending on local exposure patterns 


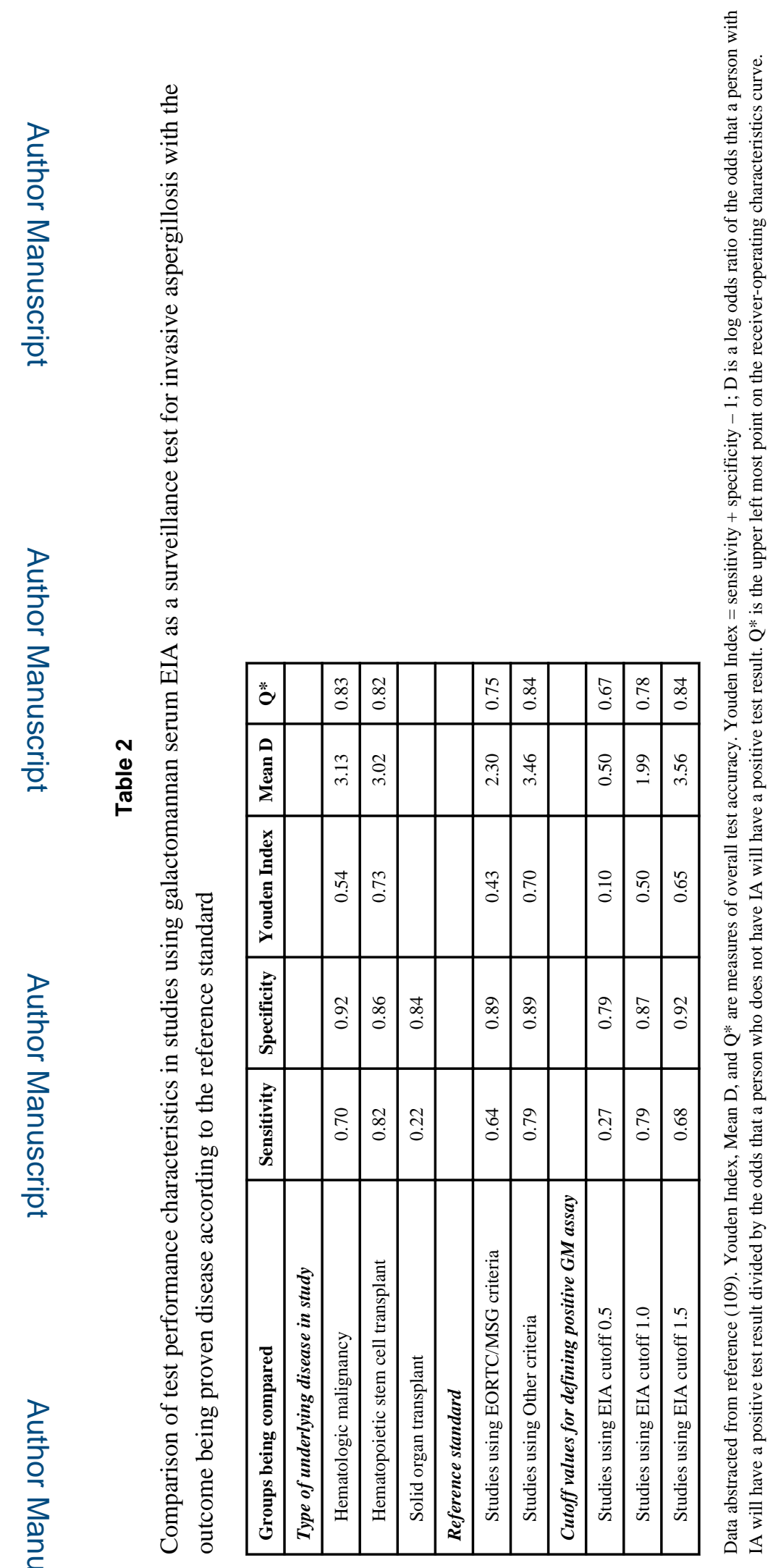

Curr Opin Pulm Med. Author manuscript; available in PMC 2016 May 01. 


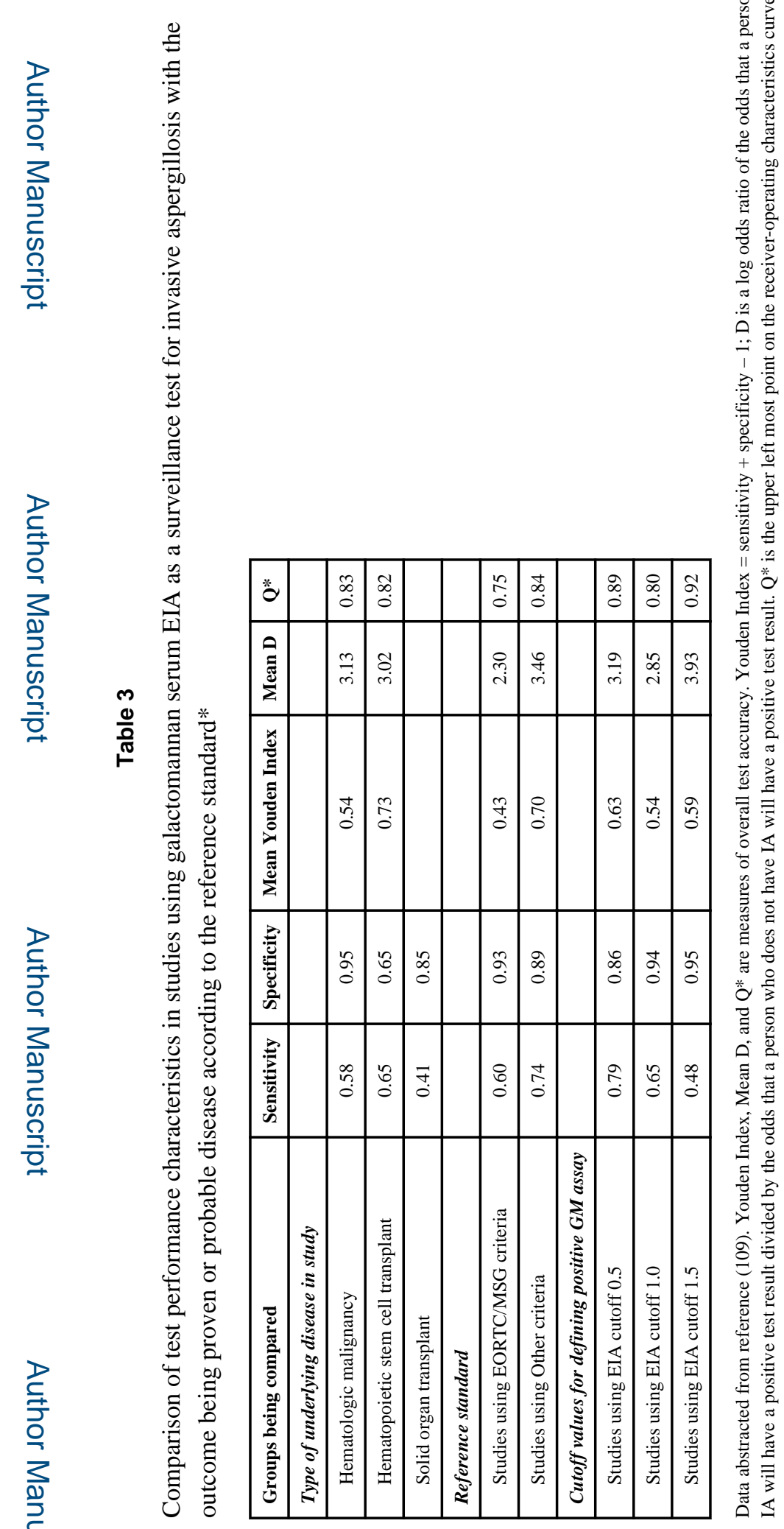

Curr Opin Pulm Med. Author manuscript; available in PMC 2016 May 01. 